УДК 339.543.012.42:341.241.8((061.1€C)+(477))

\title{
IMPACT OF THE ASSOCIATION AGREEMENT WITH THE EU ON THE DEVELOPMENT OF FOOD LAW IN UKRAINE
}

\author{
ВПЛИВ УГОДИ ПРО АСОЦАЦІЮ 3 ЄС НА РОЗВИТОК \\ ХАРЧОВОГО ЗАКОНОДАВСТВА В УКРАЇНІ
}

\section{ВЛИЯНИЕ СОГЛАШЕНИЯ ОБ АССОЦИАЦИИ С ЕС НА РАЗВИТИЕ ПИЩЕВОГО ЗАКОНОДАТЕЛЬСТВА В УКРАИНЕ}

\section{Berezovska I.}

Candidate of Legal Sciences, Research Associate of the Institute of International Relations of Taras Shevchenko National University of Kyiv. E-mail: irenhome@ukr.net

\section{Березовська I. A.}

Кандидат юридичних наук, науковий співробітник науково-дослідної частини Інституту міжнародних відносин Київського національного університету імені Тараса Шевченка. E-mail: irenhome@ukr.net

\section{Березовская И. А.}

Кандидат юридических наук, научный сотрудник научно-исследовательской части Института международных отношений Киевского национального университета имени Тараса Шевченко.

E-mail: irenhome@ukr.net

Abstract. The article notes that after signing the Association Agreement and launching free trade area between Ukraine and the EU, a new stage in the development of Ukrainian food law has begun. It is characterized by the increased impact of European Union law on the legal regulation of this sphere. The provisions of Chapter 4 "Sanitary and phytosanitary measures" of the basic for the FTA Ukraine-EU Title IV of the Association Agreement "Trade and Trade-related Matters", which serve as a legal basis for harmonization of Ukrainian legislation with EU food legislation were analyzed.

The ways of Ukrainian food law development are proved to be determined by the Strategy for the implementation of Chapter IV, Section 4 of the Association Agreement. The measures envisaged by the Strategy covering almost all areas of public health, animal health and phytosanitary regulations have been analyzed. The European food and phytosanitary law is found out to cover the territory of Ukraine as a result of the implementation of measures provided for in the Association Agreement and the above Strategy. It was emphasized that the scale of the obligations undertaken by Ukraine to harmonize the food legislation requires prompt and qualified organizational work by the Ukrainian competent authorities.

Key words: European Union, Association Agreement, food law, sanitary and phytosanitary measures, food safety, approximation of legislation, implementation strategy.

Анотація. В статі наголошується, щзо внаслідок підписання Угоди про асоиіацію та початку функціонування зони вільної торгівлі між Украӥною та ЄС розпочався новий етап розвитку українського харчового законодавства, щьо характеризується посиленим виливом права Свропейського Союзу на правове регулювання цієї галузі. Проаналізовано положення глави 4 «Санітарні та фітосанітарні заходи» базового для 3ВТ Украӥна-СС Розділу IV Угоди про асоиіацію «Торгівля та питання, пов'язані з торгівлею», щуо слу- 
жать правовою основою для гармонізачії украӥнського законодавства з харчовим законодавством СС.

Доведено, щзо напрямки подальшого розвитку украӥнського харчового законодавства визначені Стратегією імплементації Глави 4 Розділу IV Угоди про асоиіацію. Проаналізовано передбачені Стратегією заходи, які охоплюють практично всі сфери громадського здоров'я, здоров'я тварин та фітосанітарних правил. Встановлено, щзо в результаті реалізачії передбачених Угодою про асочіацією та зазначеною Стратегією заходів по суті відбудеться поширення європейського харчового та фітосанітарного законодавства на територію Украӥни. Підкреслено, щзо масштаб прийнятих Украӥною зобов 'язань щуодо гармонізації харчового законодавства вимагає оперативної та кваліфікованої організаційної роботи з боку украӥнських компетентних органів.

Ключові слова: Свропейський Союз, Угода про асочіачію, харчове законодавство, санітарні та фітосанітарні заходи, безпека харчової продукиії, гармонізація законодавства, стратегія імплементації.

Аннотация. $B$ статье отмечается, что в результате подписания Соглашения об ассоџиаџии и создания зоны свободной торговли между Украиной и ЕС начался новый этап развития украинского пищевого законодательства, который характеризуется усиленным влиянием права Европейского Союза на правовое регулирование этой отрасли. Проведен анализ положений главы 4 «Санитарные и фтосанитарни меры» базового для ЗСТ Украина-ЕС Раздела IV Соглашения об ассочиачии «Торговля и вопросы, связанные с торговлей», служащие правовой основой для гармонизаџии украинского законодательства с пищевым законодательством ЕС. Доказано, что направления развития украинского пищевого законодательства определень Стратегией имплементации Главы 4 Раздела IV Соглашения об ассоциачии. Проанализированы предусмотренные Стратегией меры, которые охватывают практически все сферы общественного здоровья, здоровья животных и фитосанитарных правил. Установлено, что в результате реализации предусмотренных Соглашением об ассоциации и указанной Стратегией мероприятий по сути произойдет распространение европейского пищевого и фитосанитарного законодательства на территорию Украины. Подчеркнуто, что масштаб принятых Украиной обязательств по гармонизачии пищевого законодательства требует оперативной и квалифицированной организационной работы со стороны украинских компетентных органов.

Ключевые слова: Европейский Союз, Соглашение об ассоциации, пищевое законодательство, санитарные и фитосанитарные мерь, безопасность пищевой продукиии, гармонизация законодательства.

The current problem. Partial enforcement of the Association Agreement between Ukraine and the European Union (AA) [1] and the launch of the deep and comprehensive free trade area between Ukraine and the EU (FTA) on 1 January 2016 marked a new stage of Ukraine - EU relations. Proceeding to the practical implementation of the Association Agreement initiated deep integration of Ukraine with the EU and became a factor that determines the future development of the legal system of Ukraine.

Food industry is one of the areas where AA provides for large-scale transformation in the national legal regulation. Given the export potential of Ukraine in the food industry, as well as effects of food legislative regulation on health of each citizen, the research of AA impact on the development of food law in Ukraine is becoming current.

Analysis of the latest publications. In the European doctrine the legal basis of food law was studied by the following scientists: A. Alemanno, C. Dalmet, S. Gabbi, B. Van der Meulen, R. 
O'Rourke, P.-M. Vincent, etc. In Ukrainian doctrine the study of food industry regulation in the EU and harmonization of relevant legislation of Ukraine has recently become the subject of special attention not only of Ukrainian scientists but of experts of specialized business associations, officials and practitioners. Among the doctrinal legal research of these issues the works of S. Bugera, T. Churilova, Ya. Dobidovska, V.Yermolenko, T. Kovalenko, V. Mamutov and other scientists are worth mentioning. However, recent trends of legal regulation of this sphere in Ukraine related to the AA entry into force require an individual research.

The purpose of the article. The purpose of this research is to determine the subject of food law regulation and project main ways of its development in Ukraine in the context of the entry into force of the Association Agreement with the EU.

The important research results. English concept of "food law" (or French la législation alimentaire), which is literally translated into Ukrainian as "harchove zakonodavstvo", is not often used in Ukrainian legal doctrine. Instead, in EU law it is common and clearly defined. Its consolidation is associated with the adoption on 28 January 2002 the basic Regulation of the European Parliament and the Council №178/2002 laying down the general principles and requirements of food law, establishing the European Food Safety Authority and laying down procedures in matters of food safety [2], that became a legislative response of the EU for a range of food incidents in the late 1990s.

The purpose of the approval of food law at EU level was introduction of an integrated approach to food safety "from farm to fork", covering all aspects of food chain, including feed production, primary production, food processing, storage, transportation and retail.

Regulation №178/2002 is the legal basis for the development of legislation on food and feed, both at EU and national levels. To this end, it sets forth the general principles, requirements and procedures underlying the decision-making on food safety and feed, covering all stages of production and distribution. Moreover, the instrument regulates basic procedures and tools for emergency response and crises, and rapid alert system for food and feed (RASFF).

Regulation introduces an independent body responsible for scientific advice and scientific and technical assistance to support legislation and EU policies in all fields which have a direct or indirect impact on food safety and animal feed - European Food Safety Authority (EFSA).

Regulation is designed to ensure a high level of protection of human life and consumer interests in relation to food, while ensuring the effective functioning of the internal market.

According to Article 3 of the said Regulation the term "food law" means the laws, regulations acts and administrative provisions governing food in general, and food safety in particular, at both EU and national levels. Food law governes any stage of production, processing and distribution of food and also of feed produced for, or fed to food-producing animals.

Definition of "food" (or "foodsuff") is enshrined in Article 2 of the Regulation and includes any substance or product, whethere processed or not, partially processed or unprocessed, intended to be, or reasonably expected to be ingested by humans. "Food" includes drink, chewing gum and any substance including water, intentionally incorporated into the food during its manufacture, preparation or treatment.

Therefore, food law in the EU covers all stages of production, processing and distribution of food and feed for farm animals.

In addition to general principles and provisions laid down in Regulation № 178/2002, EU food law includes a group of standards that focus on hygiene requirements (Hazard Analysis and Critical Control Points HACCP) - Regulation № 852/2004 of 29 April 2004 on the hygiene of foodstuffs [3]; Regulation № 853/2004 of 29 April 2004 lays down specific hygiene rules for food of animal origin [4]. 
Another group incorporates rules on the official monitoring mechanisms - Regulation № 882/2004 of 29 April 2004 on official controls performed to ensure the verification of compliance with feed and food law, animal health and animal welfare rules [5]; Regulation № 854/2004 of 29 April 2004 laying down specific rules for the organisation of official controls on products of animal origin intended for human consumption [6].

In the Ukrainian legal system the regulation of food distribution had its own history. For a long time it was based on the Soviet approach, where the state determined the standards of food production and controlled its observance. The main legal acts in this area were: Law of Ukraine "On the safety and quality of food" of 23 December 1997 [7]; Law of Ukraine "On ensuring sanitary and epidemiological welfare of population" of 24 February 1994 [8]; Law of Ukraine "On veterinary medicine" of 25 June 1992 [9]; Law of Ukraine "On Protection of Consumers' Rights" of 12 May1991 [10]; Law of Ukraine "On Standardization" of 17 May 2001 [11]; Law of Ukraine "On confirmation of compliance" of 17 May 2001 [12] and others.

With the accession to the WTO in 2008, Ukraine joined the international WTO agreements, including the Agreement on Agriculture, the Agreement on Sanitary and Phytosanitary Measures and began appropriate harmonization of its legislation with the requirements of international law.

Since the conclusion of the Association Agreement with the EU in Ukraine a new stage in the development of food law, characterized by the increased influence of the European Union in the regulation of the sphere has begun. The WTO principles and approaches to the regulation of food trade in the Association Agreement are supplemented by large-scale contractual obligations that imply the fundamental reform of the Ukrainian food law.

It should be noted that the reform was launched before the AA entry into force as a result of the adoption in 2014 of Law "On amendments to some legislative acts of Ukraine concerning food" [13] designed to harmonize Ukrainian legislation with the EU in the field of safety and food quality, ensuring a high level of protection of human health and consumer interests and the creation of transparent conditions for economic activities, increasing competitiveness of domestic food production and reducing their prices.

The above law, inter alia, amended the Law of Ukraine «On the safety and quality of food», currently the Law «On the basic principles and requirements for safety and quality of food». Currently, it regulates relations between executive authorities, food business operators and food consumers. It determines the order to ensure safety and quality of food produced, in circulation, imported (sent) to the customs territory of Ukraine and/or exported (sent) from it. Ukrainian experts recognize that law to be a reforming one and assess the level of adaptation of its provisions to EU law standards of food to be high [20 Churilova, 2015: 63].

The next step in the development of food law of Ukraine should be the regulation of the procedure for official monitoring of food safety. To this end, in 2014 the Draft Law of Ukraine «On State monitoring carried out to verify compliance with the law on safety and quality of food and feed, animal health and welfare» was drawn up and adopted [14]. The draft law specifies the requirements for the competent authorities, duties and powers of state inspectors harmonized with respective EU regulations. However, it is still awaiting for its final approval by the parliament.

Establishment of the free trade area with the EU on 1 January 2016 launched a clear mechanism for harmonization of Ukrainian legislation with EU food law provided for in the Association Agreement. Its legal basis is the basic position for the EU-Ukraine FTA, Title IV of AA «Trade and Trade-related Matters» and in particular Chapter 4 «Sanitary and phytosanitary measures», including Articles 59-74 of AA (hereinafter - Chapter 4 of the AA) and Annexes IV, V to the AA. 
According to Article 59, the objective of Chapter 4 of the AA is to facilitate the trade implementation between Ukraine and the EU covered by sanitary and phytosanitary measures (SPM) in ensuring the health of people, animals and plants, particullary by approximating Ukraine's laws to those of the EU.

Article 63 of the AA lays down the obligations of the Parties to inform each other of the peculiarities of the competent authorities. Moreover, according to Article 74 the Sub-Committee on SPM management of the Committee on Trade is established, which has an important task of implementation of Chapter 4 of the AA. In particular, the Sub-Committee will conduct regular monitoring of the implementation of the adaptation process, revise, where appropriate, amend the Annexes to Chapter 4 of the AA, provide opinions and recommendations to other bodies, draw up reports under the AA.

The EU sets forth the rules of procedure of the Sub-Committee on SPM management in Council Decision 2017/189 of 16 January 2017 [15]. Ukraine approves the organization of work of the Sub-Committee and its working group in Resolution of the Cabinet of Ministers of Ukraine № 646 of 8 July 2015 [16]. Coordination of work is performed by the Government Office for European and Euro-Atlantic Integration of the Secretariat of the Cabinet of Ministers of Ukraine, Agriculture Ministry is the Ministry responsible for the organization of the Ukrainian working group of the Sub-Committee, its head - Deputy Minister of Agriculture and Food of the European Integration.

Article 64 of the AA is the immediate legal basis for the harmonization of Ukrainian law with EU food law. In particular, it contains a clear commitment of Ukraine to approximate its sanitary and phytosanitary and animal welfare legislation in compliance with the EU legislation, as set out in Annex V to the AA. The obligations of the Parties to cooperate on legislative approximation and capacity-building were established. The responsibility of the Sub-Committee on SPM management to regularly monitor implementation of the approximation process, set out in Annex V to this Agreement, in order to provide the necessary recommendations on approximation measures was stipulated.

Obligations of Ukraine under Article 64 of the AA to submit within three months after entry into force of the AA to the SPM Sub-Committee a comprehensive strategy for the implementation of Chapter 4, divided into priority areas that relate to measures, as defined in Annex IV-A, IV-Annex B and Annex IV-C to AA facilitating trade in one specific commodity or group of commodities is of particular importance for the further development of national food law. Agreement stipulates that this strategy shall serve as a reference document for the implementation of Chapter IV and will be added to Annex V to the AA.

To fulfill these commitments the Cabinet of Ministers of Ukraine on 24 February 2016 adopted a Comprehensive Strategy for the Implementation of Chapter IV of the AA №228 (hereinafter - "the Strategy") [17], which contains a detailed list of measures agreed with systematic regulatory convergence with Ukrainian legislation, reference to the relevant EU legislation and fixes implementation periods.

Section 1 of the Strategy "Public Health" includes activities related to the issues of defining the basic principles and requirements of food and feed; State monitoring in the SPM area; labeling and information on food products. A separate section includes measures applied to products of animal origin, including the main categories of products of animal origin for human consumption (meat, fishery products, milk, eggs, food additives, flavorings, etc.).

Section 2 of the Strategy "Animal Health" includes measures applied to the main categories of live animals, measures on animal diseases, animal identification and registration, animal byproducts, feed additives and feed, standards of keeping and treating animals. 
Chapter 3 of the Strategy "Phytosanitary measures" includes measures on plants, plant products and other target objects. In particular, measures on plant health, protection of plant varieties, fertilizers, seeds and planting material, GMO monitorung.

Strategy analysis shows that its implementation plan includes almost all set of basic (horizontal) and sectoral (vertical) EU food legislation and covers more than 200 regulatory legal acts of the EU. The list of these acts is in fact impressive, ranging from the above-mentioned basic Regulation №178/2002, laying down the general principles and requirements of food law, Regulation №853/2004 laying down specific hygiene rules for products of animal origin and Regulation № 854/2004 laying down specific rules for the organisation of formal monitoring over products of animal origin intended for human consumption, including the Directive on issues of animal health and veterinary requirements to the Commission's decision on placing certain types of genetically modified foods on the market.

The Strategy sets forth the implementation period for all activities covering the period from 2016 to 2021. A bulk of the EU food legislation should be implemented in the Ukrainian legislation during 2018.

Assessment of the list of activities covering virtually all aspects of public health, animal health and phytosanitary regulations suggests that unprecedented reform of Ukrainian legislation, which resulted in extention of the European food and phytosanitary legislation to the territory of Ukraine is launched by the gradual implementation of the Strategy.

It is worth mentioning that the AA provides for the mechanism to monitor the implementation of commitments by Ukraine, including continuous assessment by the EU institutions of the status of implementation and carrying out measures and commitments by Ukraine to harmonize its legislation.

To facilitate the assessment process, the Ukrainian government to the end of these transitional periods, specified in the AA, must provide EU with progress reports on legislative approximation. Except assessments of approximation, the monitoring procedure may include a "on-the-spot missions, with the participation of EU institutions, bodies and agencies, non-governmental bodies, supervisory authorities, independent experts and others as needed" (Article 475 of the AA).

Within the framework of the FTA positive result of such monitoring is stipulated by prerequisite for the further opening of EU markets for Ukrainian businesses. One of the first examples of this was the monitoring mission of Food and Veterinary Office of the General Directorate of Health and Food Safety of the European Commission (DG SANTE), that in September 2016 checked some issues of state monitoring of food safety in Ukraine, namely monitoring of residues of veterinary drugs and contaminants in animal products. The final report containing findings and recommendations for national competent authorities was drafted in the result of the monitoring [18]. Their implementation will depend on the further opening of the EU market for Ukrainian food of animal origin.

Assessment of commitments on harmonization of food legislation adopted by Ukraine gives reason to believe that their implementation requires a skilled operative and organizational work of the Ukrainian competent authorities. The planned harmonization requires special attention of the Ukrainian government and requires highly skilled personnel. Some work on institutional support has already started: in 2014 in the structure of the Agriculture Ministry the post of Deputy Minister for European Integration was introduced, reforming of the leading competent body the State Service of Ukraine on food safety and consumer protection by creation of the State Veterinary and Phytosanitary Service was launched, joining the State Inspection of Ukraine for Consumer Rights Protection and the State sanitary and epidemiological service. However, the 
delay in the organizational transformation of the new service, which took nearly one and a half year, had an adverse impact on the development of the industry. Thus, the provision of these services was adopted only in a year, and the questions of its funding and structure were solved only in January 2016 [19]. Accordingly, only in April 2016 the formation of the central office and local offices began. Such approaches to the reform of the competent authority with a view to problem epizootic situation and many challenges in agriculture and the food industry should be urgently changed by Ukrainian government. The State Service of Ukraine on food safety and consumer protection faces the following urgent tasks: to conduct technical work on translation of EU documents into Ukrainian, to improve the mechanism for assessment of compliance of Ukrainian legislation with European one, to establish coordination between all competent authorities to implement plans on food law harmonization under the Association Agreement efficiently and timely.

Conclusions. Thus, the implementation of the Association Agreement, including the launch of a free trade area between Ukraine and the EU was the impetus for the reform of Ukrainian food legislation aimed at regulating the quality and safety of food, both on state and at manufacturing level.

A Comprehensive Strategy for the Implementation of Chaper IV of the AA became the main document that will determine the development of Ukrainian food law at least for next 5 years. Analysis of measures envisaged by the Strategy covering almost all areas of public health, animal health and phytosanitary regulations, states that as a result of its implementation the application of European food and phytosanitary law in Ukraine has begun. Such reform, due to the need of development of trade relations between Ukraine and the EU will have much broader implications both for the economy and for social relations in Ukraine.

\section{References}

1. Association Agreement between the European Union and its Member States, of the one part, and Ukraine, of the other part // Official Journal L 161, 29. 5. 2014, P. 3-2137.

2. Regulation №178/2002 of 28 January 2002 of the European Parliament and the Council laying down the general principles and requirements of food law, establishing the European Food Safety Authority and laying down procedures in matters of food safety// Official Journal L 31/1 1. 2. 2002, P. 1.

3. Regulation №852/2004 of the European Parliament and the Council of 29 April 2004 on the hygiene of foodstuffs // Official Journal L 139, 30. 4. 2004, P.1.

4. Regulation № 853/2004 of the European Parliament and the Council of 29 April 2004 laying down specific hygiene rules for food of animal origin // Official Journal L 139, 30. 4. 2004, P. 55.

5. Regulation №882/2004 of the European Parliament and the Council of 29 April 2004 on official controls performed to ensure the verification of compliance with feed and food law, animal health and animal welfare rules // Official Journal L 165, 30. 4. 2004, P. 1.

6. Regulation №854/2004 of the European Parliament and the Council of 29 April 2004 laying down specific rules for the organisation of official controls on products of animal origin intended for human consumption // Official Journal L 139, 30. 4. 2004, P. 206.

7. Law of Ukraine «On the safety and quality of food» of 23 December 1997, № 771/97-VR // Official Bulletin of Ukraine from 05.02.1998., Number 3, P. 13, Article 75, Code Act 4679/1998.

8. Law of Ukraine «On ensuring sanitary and epidemiological welfare of population» of 24 February 1994, № 4004-XII // Voice of Ukraine from 08. 04. 1994. 
9. Law of Ukraine «On veterinary medicine» of 25 June 1992, № 2498-XII // Voice of Ukraine from 24. 02. 1997.

10. Law of Ukraine «On Protection of Consumers' Rights» of 12 May1991, №1023-XII // Voice of Ukraine from 08. 06. 1991.

11. Law of Ukraine «On Standardization» of 17 May 2001, №2408-III // Voice of Ukraine from 20. 06. 2001.

12. Law of Ukraine «On confirmation of compliance» of 17 May 2001, № 2406-III // Voice of Ukraine from 26. 06. 2001.

13. Law «On amendments to some legislative acts of Ukraine concerning food» № 1602-VII of 22 July 2014 // Voice of Ukraine from 19. 09. 2014.

14. Resolution of the Verkhovna Rada of Ukraine № 1605-VII from 22. 07. 2014 on adopting a draft Law of Ukraine on State controls carried out to verify compliance with the law on safety and quality of food and feed, animal health and welfare // http://zakon2.rada.gov.ua/ laws/show/1605-18

15. Council Decision 2017/189 of 16 January 2017 // Official Journal of the European Union L 29/40 3 February 2017.

16. Resolution of the Cabinet of Ministers of Ukraine № 646 of 8 July 2015 «On organization of the Subcommittees of the Association Committee in the framework of the EU-Ukraine Association Agreement» // Governmental Courier N 170 of 16. 09. 2015.

17. Decree of Cabinet of Ministers of Ukraine №228 on 24 February 2016 "On Approval of Comprehensive Strategy for Implementation of Chapter IV (Sanitary and Phytosanitary Measures) of Title IV "Trade and Trade-related Matters" of the Association Agreement between Ukraine and the EU // Governmental Courier N 65 of 06. 04. 2016.

18. European Commission Directorate General for health and food safety Final report of an audit carried out in Ukraine from 05 september 2016 to 16 september 2016 in order to evaluate the control of residues and contaminants in live animals and animal products including controls on veterinary medicinal products DG (SANTE) 2016-8897 - MR // http://ec. europa.eu/food/audits-analysis/audit_reports/details.cfm?rep_id=3719

19. Decree of the Cabinet of Ministers of Ukraine № 76 of 27 January 2016 "Some issues of activities of the State Service of Ukraine on food safety and consumer protection"// http://www.kmu.gov.ua/control/uk/cardnpd?docid=248828510.

20. Churylova T. The issue concerning the adaptation of the Ukrainian legislation to the EU requirements in the sphere of food safety // Scientific Journal of International Humanitarian University. Series: “Law”-2015, № 14, P. 60-63. 